\title{
Innovation Union Competitiveness report 2011
}

Country profile - Austria 
(c) European Union, 2011. Reproduction is authorised provided the source is acknowledged. 


\section{COUNTRY PROFILE}

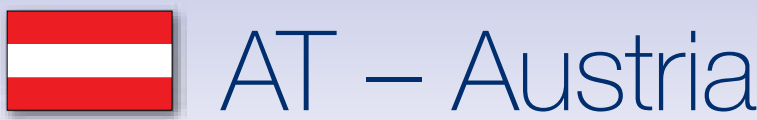

Progress towards meeting the Europe 2020 R\&D intensity target

R\&D intensity increased during the past decade, from $1.94 \%$ in 2000 to $2.79 \%$ of GDP in 2009 . This trend is significantly higher than the EU average and has allowed Austria to approach the 3\% R\&D target set for 2010.

If the trend from the last decade continued, Austria would approach an R\&D intensity of $4 \%$, positioning the country at the world forefront, with values similar to countries like Sweden, Finland, South Korea or Japan.
Both public and private $R \& D$ increased in the last decade, and in the last years, public R\&D increased anti-cyclically, compensating the decrease in the share of business R\&D due to the economic crisis. The federal government sector increased its share in overall $R \& D$ expenditures from 28\% in 2007 to 35\% in 2010, while the percentage of gross R\&D financed by industry decreased to 43\%, in comparison to $49 \%$ in 2007.

\section{AUSTRIA R\&D Intensity projections, 2000-2020(1)}

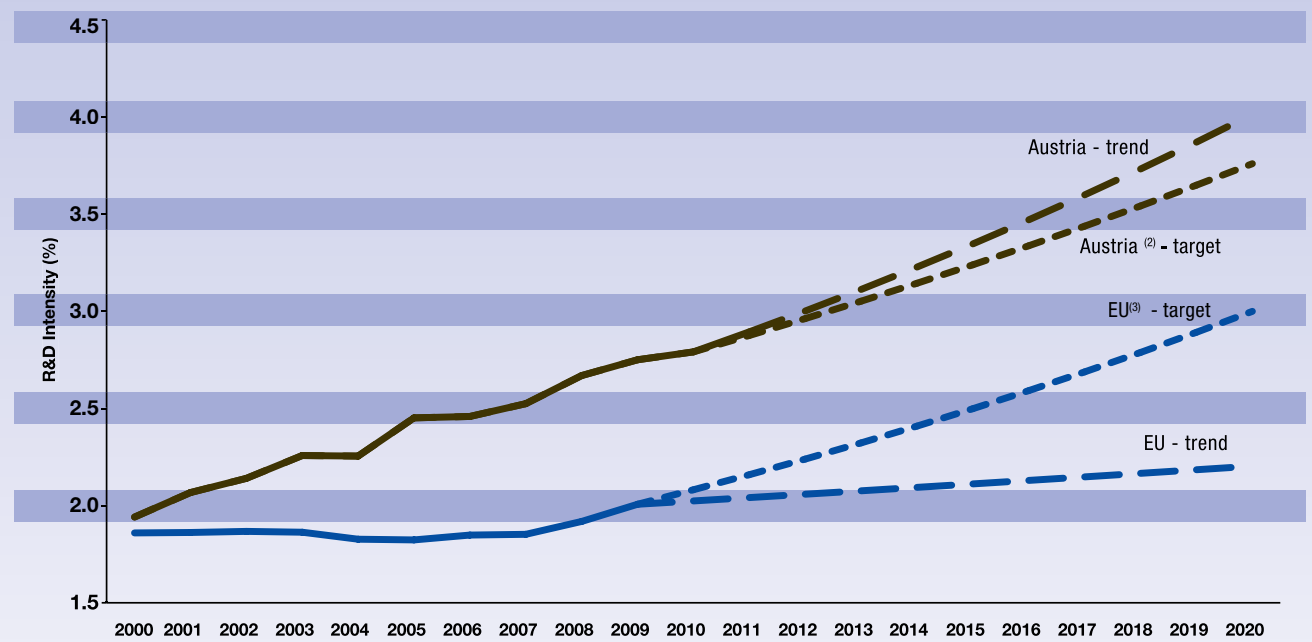

Source: DG Research and Innovation

Innovation Union Competitiveness Report 2011

Data: DG Research and Innovation, Eurostat

Notes: (1) The R\&D Intensity projections based on trends are derived from the average annual growth in R\&D Intensity

for 2000-2009 in the case of the EU and for 2000-2010 in the case of Austria.

(2) AT: This projection is based on a tentative R\&D Intensity target of $3.76 \%$ for 2020

(3) EU: This projection is based on the R\&D Intensity target of $3.0 \%$ for 2020. 


\section{Research and Innovation Performance}

The Austrian research and innovation system depicts a strong performance. The high R\&D investments, especially in the private sector, are translated both into a high quality scientific production and a strong technological inventiveness capacity. In this respect, Austria outperforms the EU on average and approaches the United States in key indicators such as the share of high-impact publications or PCT patents. Strikingly enough, the translation of these efforts into purely economic terms does not appear clearly. In particular the contribution of high-tech and mediumtech manufactured goods to the trade balance outside of EU-27 is much lower than average. This situation has been recognised by the Austrian authorities, who have launched (March 2011) a Research, Technology and Innovation Strategy with a 2020 perspective to upgrade the innovativeness level of the economy as a whole and become a country at the "technological frontier" leading to higher productivity gains.

From a dynamic perspective, in the last decade, Austria has significantly improved its scientific and technological competitiveness in virtually all dimensions, largely outperforming the EU or other similar research systems.

\section{AUSTRIA}

\section{R\&D profile, 2009 ${ }^{(1)}$}

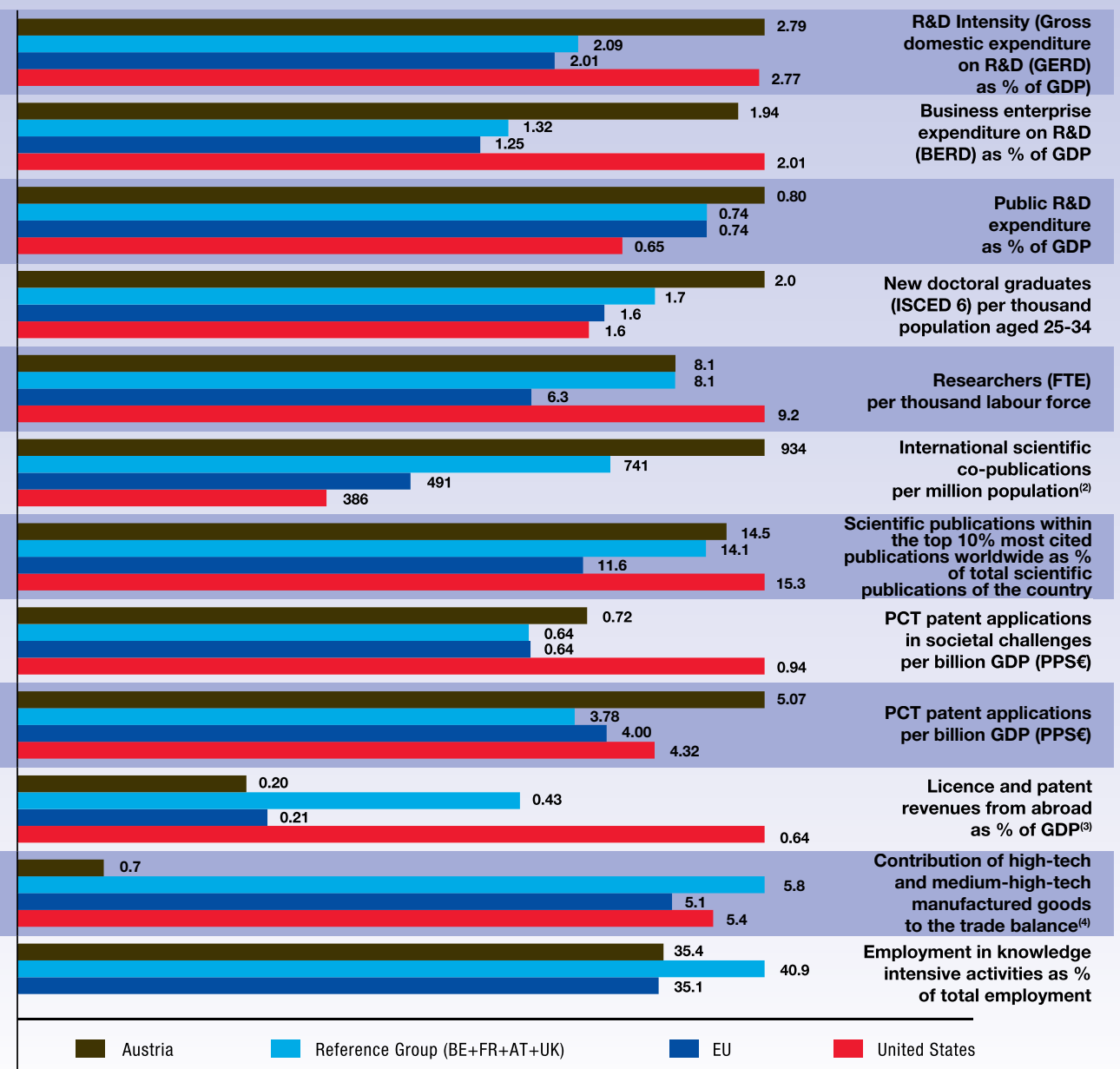

Source: DG Research and Innovation

Data: Eurostat, OECD, Science Metrix / Scopus (Elsevier)
(2) The EU value refers to the median rather than to the average. (3) EU refers to extra-EU.
(4) (i) EU does not include BG, CY, LV, LT, MT, RO; (ii) EU refers to extra-EU.
(5) Elements of estimation were involved in the compilation of the data. 


\section{AUSTRIA}

\section{Average annual growth (\%), 2000-2009(1)}

R\&D Intensity (Gross domestic expenditure on R\&D (GERD) as \% of GDP)

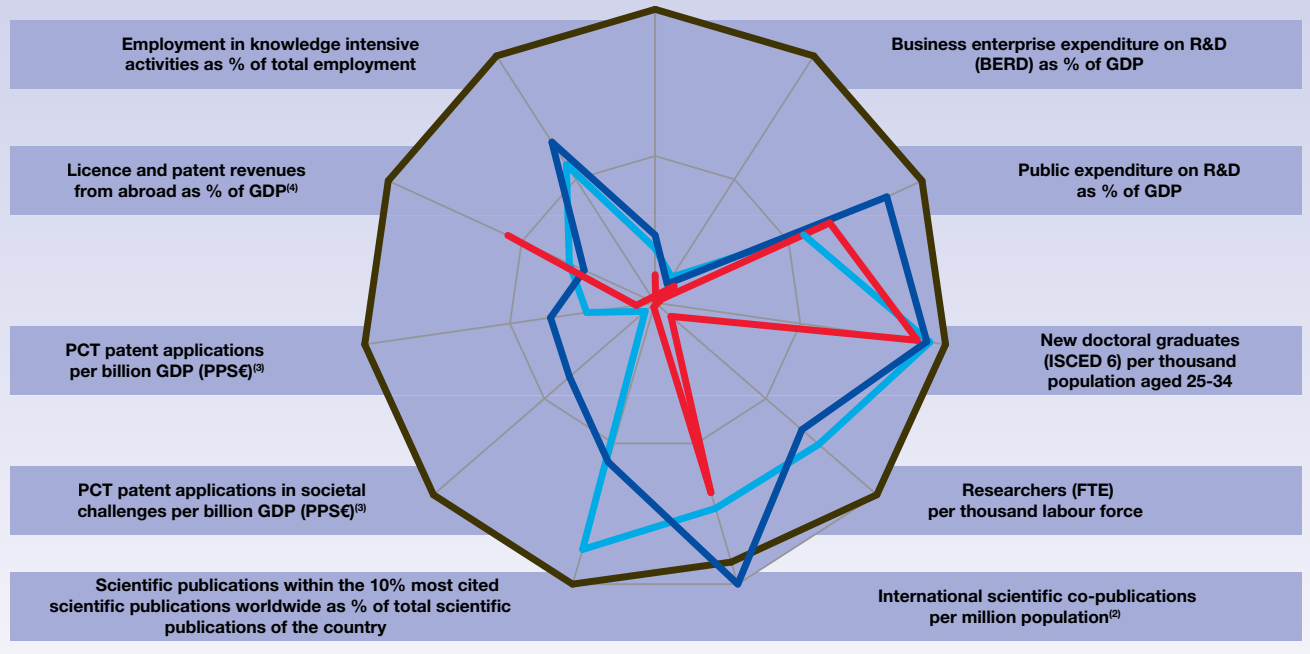

Austria

Reference Group (BE+FR+AT+UK)

EU

United States

Source: DG Research and Innovation

Innovation Union Competitiveness Report 2011

Data: Eurostat, OECD, Science Metrix / Scopus (Elsevier)

Notes: (1) Growth rates which do not refer to 2000-2009 refer to growth between the earliest available year

and the latest available year over the period 2000-2010.

(2) The EU value refers to the median rather than to the average.

(3) Average annual growth refers to real growth

(4) EU refers to extra-EU.

(5) Elements of estimation were involved in the compilation of the data.

\section{AUSTRIA}

\section{Co-publications between Austria and European Countries in 2000-2009}

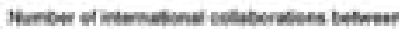

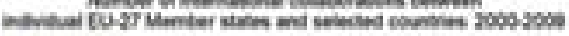

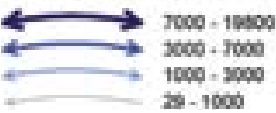

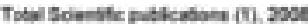

$00000-1200000$

$80000-80000$

$10000-\$ 0000$

$1000-10000$

$200-1000$

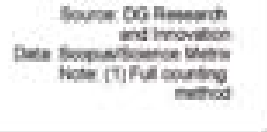

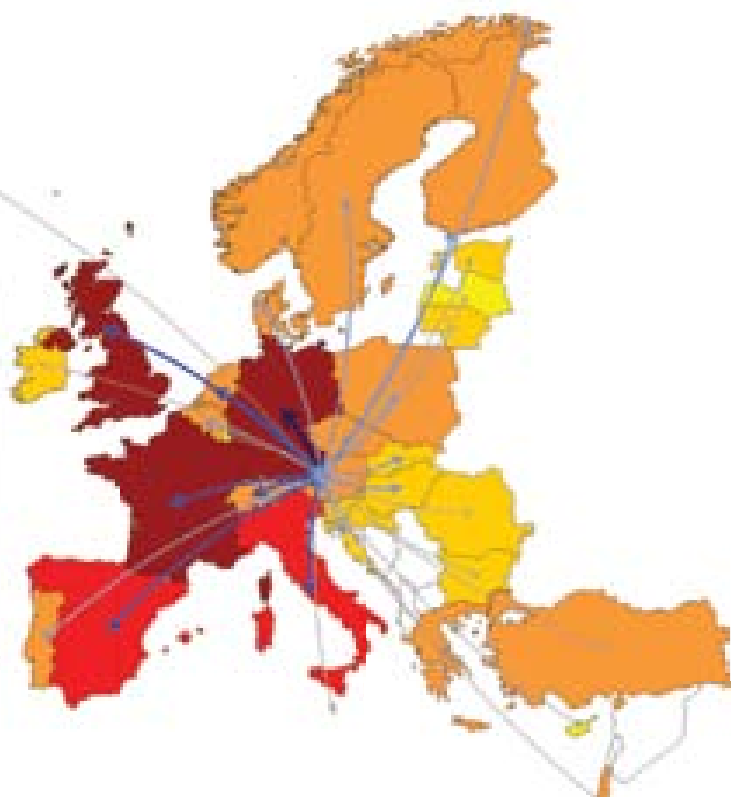




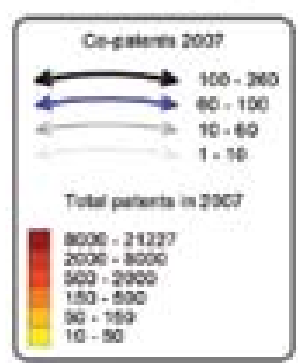

Source: DG Research and Innovation Data: Eurostat, EPO

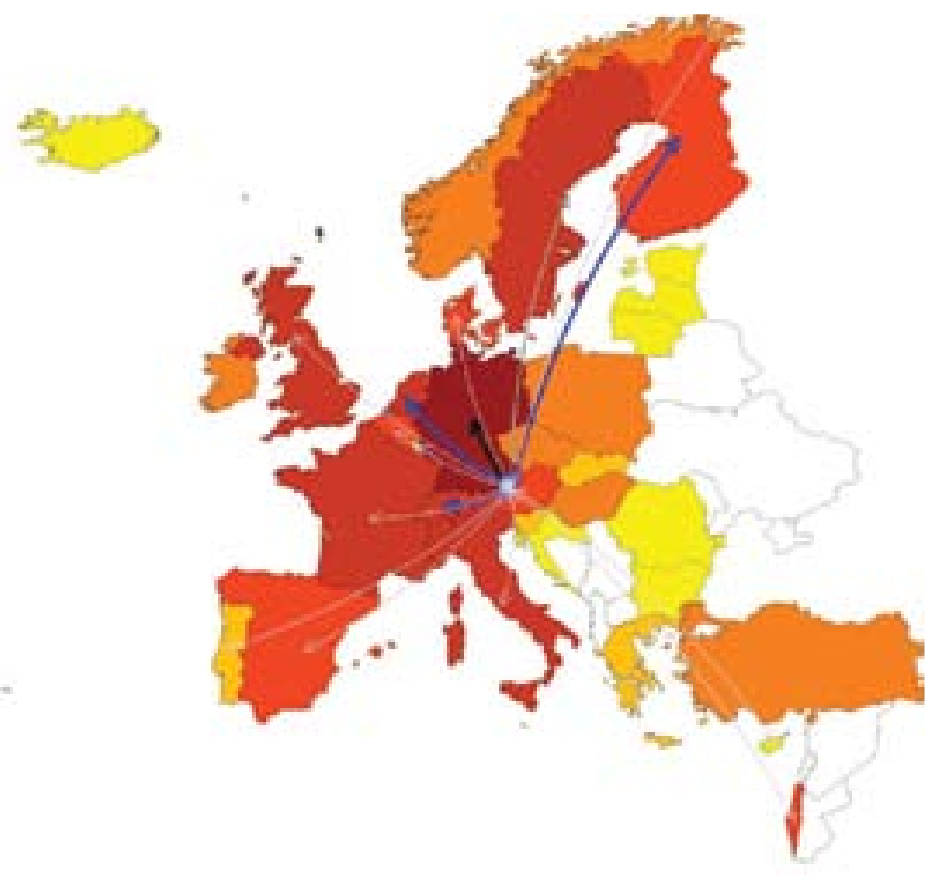

\section{Structural change towards a more knowledge- intensive economy}

\section{Area: Scientific and Technological collaborations}

Austria is a rather small but open research and innovation system which can benefit from strong knowledge spillovers, as evidenced by the large number of increasing international scientific co-publications. If the main scientific partner is Germany, due to its size and the linguistic and historical ties between the two countries, Austria has significant collaborations with a number European country.

In terms of co-invented patents, the main technological partner is once again Germany, but Switzerland, the Netherlands and Finland also rank high in the list. In case of higher Industry -University cooperation, progress in co-patenting activity with countries such as France, Spain, the United Kingdom and Italy would allow Austria to take better benefit from scientific cooperation existing with these latter countries.

The geographical, historical and cultural factors that reflect in the industrial ties influence the technological cooperation pattern.
As mentioned earlier, private R\&D intensity grew in Austria in the last decade in almost all sectors. To a large extent, this increase can be traced back to two main sources: (1) an increase of the importance of some medium-high and high tech sectors such as motor vehicles and chemicals and chemical products, in the overall Austrian economy, and (2) an increase in the research intensity, i.e. R\&D investment as a percentage of total value added, of some key medium-high tech and high tech sectors such as electric machinery and apparatus, medical precision and optical instruments or machinery equipment. Despite this progress, the average R\&D intensity of most Austrian manufacturing sectors remains similar to Germany, but slightly below leading countries such as Sweden or France'.

As a result, the Austrian manufacturing sector may find new opportunities to move even further towards higher research-intensive, more value added products in the global added value chain of some specific sectors.

1 Private R\&D intensity, i.e; R\&D investment over total value added in manufacturing in 2006 was of $6.83 \%$ in Austria, $7.54 \%$ in Germany, $10.05 \%$ in France and $13.23 \%$ in Sweden. (source: DG Research and Innovation) 


\section{AUSTRIA}

\section{Share of value added versus BERD Intensity - Average annual growth,} 1998-2006

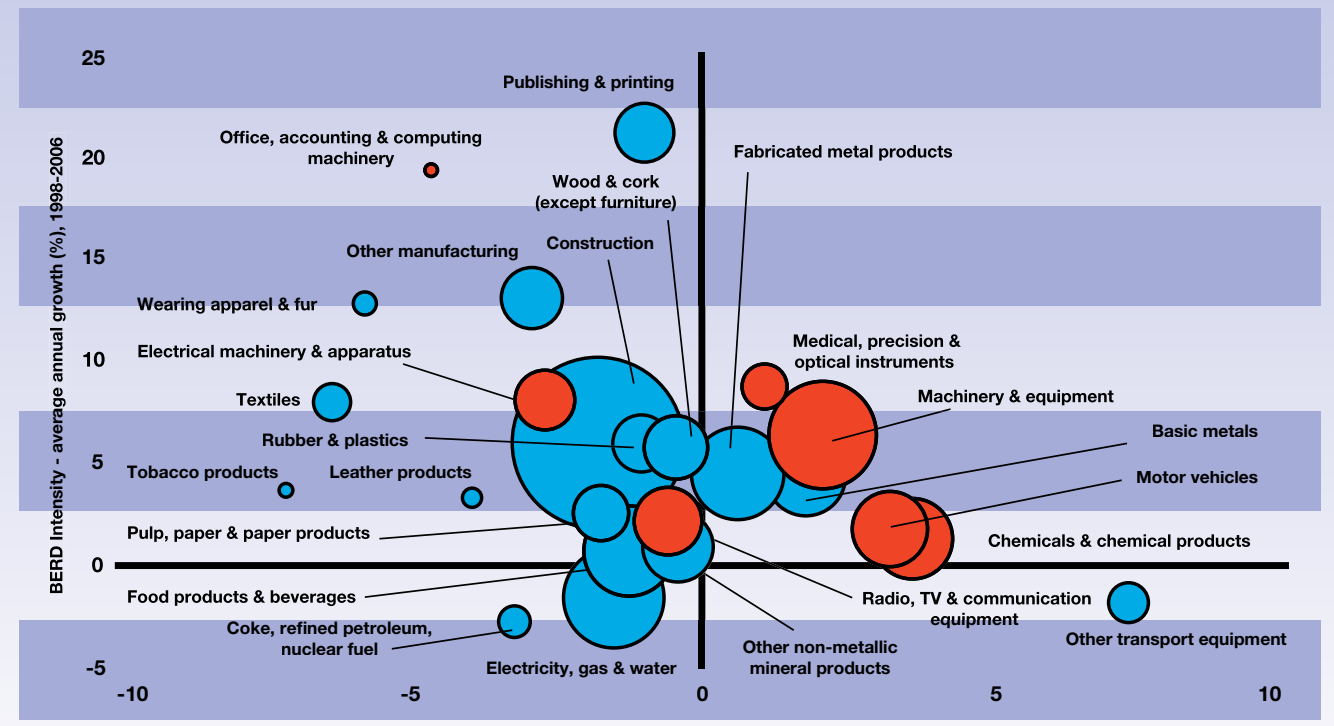

Share of value added in total value added - average annual growth (\%), 1998-2006

Source: DG Research and Innovation

Innovation Union Competitiveness Report 2011 Data: OECD

Notes: (1) High-Tech and Medium-High-Tech sectors are shown in red. 'Other transport equipment' includes High-Tech,

Medium-High-Tech and Medium-Low-Tech.

(2) 'Recycling' is not included on the graph.

FP7 Key facts and figures

\section{Applications}

As of 2011/03/16, a total of

- 5918 eligible proposals were submitted in response to $248 \mathrm{FP7}$ calls for proposals

- involving 8080 applicants from Austria (3.03\% of EU-27*) and

- requesting EUR $2613.05 \mathrm{~m}$ of EC contribution $\left(2.96 \%\right.$ of EU- $\left.27^{\star}\right)$

Among the EU-27* Austria (AT) ranks:

- $10^{\text {th }}$ in terms of number of applicants and

- $10^{\text {th }}$ in terms of requested EC contribution

\section{Success rates}

- The AT applicant success rate of $21.4 \%$ is similar to the EU-27* applicant success rate of $21.6 \%$.

- The AT EC financial contribution success rate of $20.4 \%$ is similar to the EU- $27^{\star}$ rate of $20.7 \%$.

Specifically, following evaluation and selection, a total of

- 1286 proposals were retained for funding (21.7\%) involving 1733 (21.4\%) successful applicants from Austria and

- requesting EUR $532.27 \mathrm{~m}$ (20.4\%) of EC financial contribution

Among the EU-27*, Austria (AT) ranks:

- $12^{\text {th }}$ in terms of applicants success rate and

- $9^{\text {th }}$ in terms of EC financial contribution success rate

\section{Signed grant agreements}

As of 2011/03/16, Austria (AT) participates in

- 1087 signed grant agreements

- involving 13517 participants of which 1477 (10.93\%) are from Austria

- benefiting from a total of EUR $3920.46 \mathrm{~m}$ of EC financial contribution of which EUR $477.66 \mathrm{~m}$ (12.18\%) is dedicated to participants from Austria.

Among the EU-27* in all FP7 signed grant agreements, Austria (AT) ranks:

- $10^{\text {th }}$ in number of participations and

- $10^{\text {th }}$ in budget share

\section{SME performance and participation}

- The AT SME applicant success rate of $18.48 \%$ 
is similar to the EU-27 ${ }^{\star}$ SME applicant success rate of $19.33 \%$.

- The AT SME EC financial contribution success rate of $17.74 \%$ is similar to the corresponding EU- $27^{\star}$ rate of $18.26 \%$.

Specifically,

- 2673 AT SME applicants requesting EUR $742.45 \mathrm{~m}$

- $494(18.48 \%)$ successful SMEs requesting EUR $131.70 \mathrm{~m}(17.74 \%)$

In signed grant agreements, as of 2011/03/16,

a 318 AT SME grant holders, i.e., $21.53 \%$ of total AT participation

v EUR $89.66 \mathrm{~m}$, i.e., $18.77 \%$ of total AT budget share

\section{Top 3 collaborative links with}

- DE - Germany (2067)

- UK - United Kingdom (1205)

- FR - France (1 109)

${ }^{\star *} \mathrm{Nr}$. of Researchers as $\%$ of population

Rank in EU-27*

Innovation scoreboard (2008)

- Above EU-27 average

- Innovation Follower

Nr. of FP7 applicants

(\% EU-27*)

(3.03\%)

8080

Req. EC contribution

by FP7 applicants in EUR million

$\left(\% \mathrm{EU}-27^{\star}\right)$

2613.05

(2.96\%)

88295

Nr. of successful FP7 applicants

$\left(\% \mathrm{EU}-27^{\star}\right)$

1733

(2.93\%)

59199

Req. EC contribution

by successful FP7 applicants

in EUR million

(\% EU-27*)

(2.91\%)

Success rate FP7 applicants

Success rate

FP7 EC contribution

$\mathrm{Nr}$. of FP7 grant holders

(\% EU-27*)

(2.88\%)

EC contribution

to FP7 grant holders

in EUR million

(\% EU-27*)

(2.88\%)

Nr. of FP7 coordinators

(\% of grant holders)

(19.70\%)

(18.30\%)

N/A $\quad 0.40 \% \quad$ Nr. of FP7 SME grant holders

$\%$ of grant holders)

(21.53\%)

(17.25\%)

EC contribution to FP7 SME grant holders in EUR million

(\% of grant holders)

(18.77\%)

(13.32\%)
532.27

18262.02

$21.4 \% \quad 21.6 \%$

$20.4 \% \quad 20.7 \%$

1477

51279

477.66

16578.15

291

9383

318

8845

89.66

2207.73

$331-2000$

$171-330$

$71-170$

$21-70$

$1-20$ 
TABLE 1

AT - Austria - Most active FP7 research priority areas by number of applicants applying for the research projects

\begin{tabular}{|c|c|c|c|c|c|c|}
\hline FP7 priority area & $\begin{array}{c}\text { Nr. of } \\
\text { applicants }\end{array}$ & $\begin{array}{c}\text { Requested } \\
\text { EC } \\
\text { contribution } \\
\text { by } \\
\text { applicants } \\
\text { (M euro) }\end{array}$ & $\begin{array}{c}\text { Nr. of } \\
\text { mainlisted } \\
\text { applicants }\end{array}$ & $\begin{array}{c}\text { Success } \\
\text { Rate } \\
\text { (applicants) }\end{array}$ & $\begin{array}{l}\text { Requested } \\
\text { EC } \\
\text { contribution } \\
\text { by } \\
\text { mainlisted } \\
\text { applicants } \\
\text { (M euro) }\end{array}$ & $\begin{array}{l}\text { Success } \\
\text { Rate } \\
\text { (requested } \\
\text { EC } \\
\text { contribution) }\end{array}$ \\
\hline $\begin{array}{l}\text { Information and } \\
\text { Communication } \\
\text { Technologies }\end{array}$ & 2069 & 799.51 & 370 & $17.88 \%$ & 152.14 & $19.03 \%$ \\
\hline Marie-Curie Actions & 950 & $\mathrm{n} / \mathrm{a}$ & 226 & $23.79 \%$ & $\mathrm{n} / \mathrm{a}$ & $\mathrm{n} / \mathrm{a}$ \\
\hline Health & 671 & 289.71 & 148 & $22.06 \%$ & 66.98 & $23.12 \%$ \\
\hline $\begin{array}{l}\text { Environment } \\
\text { (including Climate } \\
\text { Change) }\end{array}$ & 651 & 189.50 & 135 & $20.74 \%$ & 32.58 & $17.19 \%$ \\
\hline $\begin{array}{l}\text { Research for the } \\
\text { benefit of SMEs }\end{array}$ & 641 & 88.75 & 105 & $16.38 \%$ & 14.61 & $16.46 \%$ \\
\hline $\begin{array}{l}\text { Transport (including } \\
\text { Aeronautics) }\end{array}$ & 524 & 150.76 & 140 & $26.72 \%$ & 41.16 & $27.30 \%$ \\
\hline
\end{tabular}

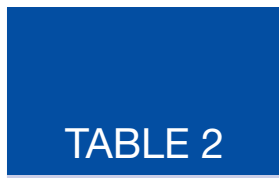

AT - Austria - Most active FP7 research priority areas by EC contribution granted to the research projects

\begin{tabular}{l|c|c|c|c}
\hline \multicolumn{1}{|c|}{ FP7 priority area } & $\begin{array}{c}\text { Number of } \\
\text { grant holders }\end{array}$ & $\begin{array}{c}\% \text { of all AT } \\
\text { grant holders }\end{array}$ & $\begin{array}{c}\text { EC } \\
\text { contribution } \\
\text { (EUR million) }\end{array}$ & $\begin{array}{c}\text { \% of total EC } \\
\text { contribution } \\
\text { to AT }\end{array}$ \\
\hline $\begin{array}{l}\text { Information and Communication } \\
\text { Technologies }\end{array}$ & 375 & $25.39 \%$ & 141.26 & $29.57 \%$ \\
\hline ERC & 45 & $3.05 \%$ & 63.38 & $13.27 \%$ \\
\hline $\begin{array}{l}\text { Health } \\
\text { Marie-Curie Actions }\end{array}$ & 136 & $9.21 \%$ & 59.77 & $12.51 \%$ \\
\hline $\begin{array}{l}\text { Transport (including Aeronautics) } \\
\text { Nanosciences, Nanotechnologies, }\end{array}$ & 184 & $12.46 \%$ & 42.94 & $8.99 \%$ \\
\hline $\begin{array}{l}\text { Materials and new Production } \\
\text { Technologies - NMP }\end{array}$ & 88 & $7.85 \%$ & 33.23 & $6.96 \%$ \\
\hline
\end{tabular}

Notes: Report generated on: 2011/03/25.02:14 PM

FP7 proposal and application figures are valid as of 2011/03/16

FP7 grant agreements and participation figures are valida as of 2011/03/16

${ }^{\star} \mathrm{EU}-27$ includes the 27 country-members and JRC as a separate entity

**E-STAT Reference year: 2007

${ }^{* \star}$ European Innovation Scoreboard is available at the website of DG Enterprise and Industry 
TABLE 3

AT - Austria - Participation in the FP7 research projects by organisation activity type

\begin{tabular}{c|c|c|c|c|c|c|c|c|c}
\hline & $\begin{array}{c}\text { Requested } \\
\text { EC } \\
\text { Activity } \\
\text { Type }\end{array}$ & $\begin{array}{c}\text { Nr. of } \\
\text { applicants } \\
\text { contribution } \\
\text { by } \\
\text { applicants } \\
\text { (M euro) }\end{array}$ & $\begin{array}{c}\text { Nr. of } \\
\text { mainlisted } \\
\text { applicants }\end{array}$ & $\begin{array}{c}\text { Success } \\
\text { rate } \\
\text { (applicants) }\end{array}$ & $\begin{array}{c}\text { Requested } \\
\text { EC } \\
\text { contribution } \\
\text { by } \\
\text { mainlisted } \\
\text { applicants } \\
\text { (M euro) }\end{array}$ & $\begin{array}{c}\text { Success } \\
\text { rate } \\
\text { (requested } \\
\text { contribution) }\end{array}$ & $\begin{array}{c}\text { Nr. of } \\
\text { grant } \\
\text { holders }\end{array}$ & $\begin{array}{c}\text { EC } \\
\text { contribution } \\
\text { to grant } \\
\text { holders }\end{array}$ & $\begin{array}{c}\% \text { ot total EC } \\
\text { contribution } \\
\text { to grant } \\
\text { holders }\end{array}$ \\
\hline HES & 3274 & 901.54 & 662 & $20.22 \%$ & 172.33 & $19.12 \%$ & 582 & 217.19 & $45.47 \%$ \\
PRC & 2167 & 635.72 & 465 & $21.46 \%$ & 142.68 & $22.44 \%$ & 441 & 137.86 & $28.86 \%$ \\
\hline REC & 1534 & 493.23 & 340 & $22.16 \%$ & 106.00 & $21.49 \%$ & 324 & 101.83 & $21.32 \%$ \\
\hline OTH & 522 & 117.38 & 94 & $18.01 \%$ & 21.99 & $18.74 \%$ & 40 & 5.22 & $1.09 \%$ \\
PUB & 342 & 73.32 & 132 & $38.60 \%$ & 18.67 & $25.46 \%$ & 90 & 15.56 & $3.26 \%$ \\
\hline SME & 2673 & 742.45 & 494 & $18.48 \%$ & 131.70 & $17.74 \%$ & 318 & 89.66 & $18.77 \%$ \\
\hline
\end{tabular}

HES - Higher or secondary education, PRC - Private for profit (excl. education), REC - Research organisations, OTH - Others, PUB - Public body (excl. research and education)

\section{TABLE 4}

\section{AT - Austria - The most active NUTS3 regions,} by EC contribution granted to the FP7 research projects

\begin{tabular}{|l|c|c|c|c}
\hline \multicolumn{1}{|c|}{ AT - Austria region } & $\begin{array}{c}\text { Number of } \\
\text { grant holders }\end{array}$ & $\begin{array}{c}\% \text { of all AT - } \\
\text { Austria grant } \\
\text { holders }\end{array}$ & $\begin{array}{c}\text { EC } \\
\text { contribution } \\
\text { (M euro) }\end{array}$ & $\begin{array}{c}\% \text { of total EC } \\
\text { contribution } \\
\text { to AT }\end{array}$ \\
\hline Wien (AT130) & 768 & $52.00 \%$ & 239.35 & $50.11 \%$ \\
\hline Graz (AT221) & 206 & $13.95 \%$ & 81.44 & $17.05 \%$ \\
\hline Innsbruck (AT332) & 97 & $6.57 \%$ & 42.52 & $8.90 \%$ \\
\hline Linz-Wels (AT312) & 74 & $5.01 \%$ & 17.84 & $3.73 \%$ \\
\hline Wiener Umland/So' $1 / 20{ }^{\prime} 1 / 2$ dteil (AT127) & 49 & $3.32 \%$ & 14.36 & $3.01 \%$ \\
\hline
\end{tabular}

\section{TABLE 5}

AT - Austria - Most active organisations in terms of EC contribution granted to the FP7 research projects

\begin{tabular}{l|c|c|c|c}
\hline \multicolumn{1}{c|}{ Legal Name } & $\begin{array}{c}\text { Number of } \\
\text { Participations }\end{array}$ & $\begin{array}{c}\text { \% of all AT } \\
\text { grant holders }\end{array}$ & $\begin{array}{c}\text { EC } \\
\text { contribution } \\
\text { (M euro) }\end{array}$ & $\begin{array}{c}\text { \% of total EC } \\
\text { contribution } \\
\text { to AT grant } \\
\text { holders }\end{array}$ \\
\hline Technische Universitaet Wien (TU WIEN) & 100 & $6.77 \%$ & 34.95 & $7.32 \%$ \\
\hline Universitaet Wien (Univie) & 81 & $5.48 \%$ & 31.79 & $6.66 \%$ \\
Universitaet Innsbruck (UIBK) & 50 & $3.39 \%$ & 25.46 & $5.33 \%$ \\
\hline Technische Universitaet Graz (TU GRAZ) & 64 & $4.33 \%$ & 25.43 & $5.32 \%$ \\
\hline Medizinische universitaet wien & 52 & $3.52 \%$ & 23.46 & $4.91 \%$ \\
\hline
\end{tabular}

